\title{
Moribundas habladoras: contestaciones al ideario patriarcal en El Conspirador (1892), Incurables (1905) y La rosa muerta (1914) ${ }^{1}$
}

\section{Tallkative Moribund Women: Confronting the Patriarchal Imaginary in EI Conspirador(1892), Incurables (1905), and La rosa muerta (1914)}

\section{Luz Ainaí Morales-Pino}

Universidad Nacional Mayor de San Marcos, Lima, Perú

Contacto: Imoralesp@unmsm.edu.pe

https://orcid.org/0000-0001-9339-5731

\section{RESUMEN}

Desde un marco de estudios literarios feministas, este trabajo analiza tres textos de distintos momentos del entre siglos latinoamericano: El Conspirador (Autobiografía de un hombre público) (1892), de la escritora peruana Mercedes Cabello de Carbonera; Incurables, de la venezolana Virginia Gil de Hermoso (1905) y La rosa muerta (1914), de la peruana Aurora Cáceres. El objetivo es ahondar en las maneras en que las mujeres de letras del periodo, en medio de sus distancias éticas, estéticas e ideológicas, confrontaron las construcciones hegemónicas de lo femenino, tanto desde el ideario burgués-liberal que privilegió el modelo de la madre republicana y el ángel del hogar paradigmático de la virtud doméstica; como desde el ideario modernista-decadentista masculino, con la idealización del arquetipo de la bella enferma, la bella muerta o la femme fatale. Las protagonistas de estas novelas emprenden proyectos de subjetivación que las desmarcan de la condición genérica impuesta al sujeto/objeto femenino con el descarte de la maternidad y el extrañamiento de la domesticidad; al tiempo que convergen en devenir, en su lecho de muerte, variantes de moribundas habladoras cuya elocuencia y agencia las torna en arquetipos contradiscursivos respecto a la silente, inmóvil, pasiva bella enferma celebrada desde el modernismo decadentista.

Palabras clave: Mercedes Cabello; Virginia Gil de Hermoso; Aurora Cáceres; Modernismo; Feminismo

\section{ABSTRACT}

From a gender/feminist perspective of literary studies, this paper analyzes the contestations to the hegemonic imaginaries of the feminine in three novels from Latin America's turn of the century: El Conspirador (Autobiografía de un hombre público) (1892), by Peruvian writer Mercedes Cabello; Incurables (1905), by the Venezuelan writer, Virginia Gil de Hermoso; and La rosa muerta (1914), by Peruvian writer Aurora Cáceres. Within their ethicalaesthetical and ideological differences, these novels defy the constructions of "the feminine" from both, the bourgeois paradigm that reduces women to the role of "republican mothers", and angels of the house marked by domestic virtue; as well as the patriarchal modernista -decadentista imaginary that idealizes female's sickness and death, or its fatal erotism (represented by the femme fatale). The novels' main characters perform processes of subjectivation that emancipate them from the generic condition imposed to the female subject/object, since they discard motherhood and tension domesticity. Furthermore, in their deathbed, these characters become variants of the talkative moribund, which's eloquence and agency turns them into counter-discursive archetypes of the silent, inert, passive and ideally beautiful sick women idealized by modernista male writers.

Keywords: Mercedes Cabello; Virginia Gil de Hermoso; Aurora Cáceres; Modernism; Feminism 


\section{Introducción}

Este trabajo aborda un conjunto de textos de tres momentos del entresiglos latinoamericano para analizar las maneras en que las escritoras del período erosionaron los arquetipos hegemónicos de feminidad, tanto desde el proyecto burgués-liberal que privilegió el modelo de la madre republicana y la virtud doméstica ${ }^{2}$; como desde el ideario modernista masculino, con la idealización del arquetipo de la bella enferma, la bella muerta o la femme fatale, esta última tan atractiva como amedrentadora para las masculinidades en crisis del período. En medio de sus diferencias estéticoideológicas y los distintos lugares de enunciación de sus autoras, las novelas El Conspirador (1892), de Mercedes Cabello (Moquegua, 1895-Lima, 1909), Incurables (1905), de Virginia Gil de Hermoso (Coro, 1856-1912) y La rosa muerta (1914), de Aurora Cáceres (Lima, 1877-Madrid, 1958) ${ }^{3}$, convergen en presentar personajes femeninos que extrañan el paradigma de "ultrafeminidad" (Frederick, 2006, p. 102) propio de las narrativas tradicionales de formación nacional, pero también adoptan, adaptan y vulneran los arquetipos de la bella enferma, la bella muerta y la femme fatale celebrados desde el modernismo. Mientras los textos modernistas representan feminidades cuya belleza o deseabilidad crece a medida que aumenta su pasividad, su silencio, su ausencia de agencia y racionalidad (esta última inversamente proporcional a su sexualidad, en el caso de la femme fatale), las mujeres que protagonizan estos relatos participan de rasgos que, si bien las vincularían, en alguna medida, con tales arquetipos, los tensionan con su capacidad de movimiento, agencia y elocuencia, sobre todo en la enfermedad y la muerte.

En esta investigación, propongo una lectura feminista una lectura feminista de estas producciones, entendidas como textos angulares para comprender, en clave de heterogeneidad, las distintas contestaciones articuladas por las escritoras frente a los modelos de feminidad celebrados desde los órdenes sociales e ideológicos dominantes y frente a los idearios éticoestéticos hegemónicos del período. El prototipo de la bella enferma/bella muerta y la femmefatale, que se torna más hermosa a medida que se agrava su enfermedad y, de forma concomitante, su silencio e inmovilidad, o que destruye a los hombres con su sexualidad perversa, son los "referentes polémicos" (Amorós, 2005a, p. 39) a los que contestan estas autoras con sus obras y los recorridos vitales de sus protagonistas ${ }^{4}$. Así, este artículo se inserta en la línea de investigaciones orientadas a rastrear el silenciado diálogo que las escritoras del entresiglos entablaron frente a los imaginarios sociosexuales y culturales hegemónicos en el campo literario, social e intelectual de su tiempo; ejercicio que busca continuar creando las condiciones de posibilidad para una lectura complejizadora del período y una concomitante problematización de las taxonomías estético-ideológicas establecidas por la tradición crítica en el intento de sistematizar la historia literario-cultural latinoamericana ${ }^{5}$.

Pese a las distancias ideológicas y éticas entre el ideario modernista devenido hegemónico a nivel del campo literario-intelectual y los valores positivista-burgueses dominantes en el orden social, estos convergen en la reducción de lo femenino a esferas otras, despolitizadas y desintelectualizadas, de la vida social. Además, los modelos de la mujerángel del hogar y las antagónicas, improductivas y antiburguesas bellas muertas, bellas enfermas y feme fatales $^{6}$ tienen en común la negación de la capacidad de ejercicio intelectual y artístico femenino ${ }^{7}$ y, sobre todo, la negación de la posibilidad de singularización y de desvinculación de la "mujer" de la condición genérica que se le impone desde el ideario patriarcal (Amorós, 1991, p. 48; Torres-Pou, 1998, pp. 2324). En ambos casos, las mujeres quedan reducidas a la condición de arquetipo universalizado que las constituye como pura naturaleza, sentimiento y emoción acrítica. Desde el ideario burgués-liberal, son posicionadas en el pedestal que les confiere su rol esencial y esencialista como las grandes reproductoras de la especie, las figuras centrales y soberanas del hogar cuyos únicos destinos posibles son el matrimonio y la maternidad (Amorós, 1991, p. 27; Torres-Pou, pp. 23-24); y, desde el ideario modernista masculino, son ensalzadas bien sea por su hípersexualización y exceso de corporalidad, como en el caso de la femme fatale; o por la carencia de esos mismos aspectos (corporalidad y sexualidad), tal como sucede con las bellas muertas-bellas enfermas celebradas desde el modernismo, las cuales conservan, en tanto que enfermas o muertas, la pureza del ideal femenino patriarcal modernista ${ }^{9}$. 
$\mathrm{Al}$ apropiarse y resignificar estos imaginarios hegemónicos de lo femenino, las escritoras dan cuenta de un posicionamiento que, paradójicamente, dialoga con la forma en que los escritores del entresiglos se desligaron del paradigma del letrado (prototipo de masculinidad a través del cual habrían obtenido legitimidad y centralidad en la primera parte del siglo XIX) ${ }^{10}$, como una manera de demostrar su postura crítica respecto a un proyecto de modernidad al que consideran como problemático, desencontrado, fallido o insuficiente (Ramos, 2009, pp. 225-227). Así, buena parte de las masculinidades "modernistas" del entresiglos, con sus "sensibilidades amenazadas" (Montaldo, 1995, p. 78), se vincularon con idearios de marginalidad, antinormatividad e improductividad que entablan una relación ideológica con los prototipos de feminidades patológicas, no maternales y problemáticamente domésticas que presentan las novelas aquí analizadas y que dan cuenta de las estrategias mediante las cuales las escritoras buscaron también otro tipo de lugar de enunciación desvinculado de la "función ideologizante" (Ramos, 2009, p. 141) que se les había asignado y con la que ellas mismas se habían legitimado en el período de la formación nacional: la madre republicana.

El análisis de estos tres textos que propongo a continuación se articula en orden cronológico, pero, sobre todo, en línea con el tipo de subversiones que plantean las novelas frente a los imaginarios hegemónicos de lo femenino, las contestaciones y dislocaciones semánticas e ideológicas que vehiculizan frente a los prototipos idealizados de la feminidad dentro del modernismo y el decadentismo y su desvinculación gradual y progresiva del paradigma de enunciación de la madre republicana.

\section{La centralidad de los márgenes: la condición angular de la anti-Ofelia en El Conspirador}

El conspirador. Autobiografía de un hombre público, de la escritora peruana Mercedes Cabello de Carbonera (1892), se presenta como el relato autobiográfico de Jorge Bello escrito hacia el final de su proyecto político, con supuestos fines ejemplarizantes. Militar cobarde, político fallido y conspirador frustrado, Bello narra un trayecto vital antiheroico donde destacan como escenas recurrentes sus huidas de la autoridad, siendo siempre rescatado por personajes femeninos que no solo lo van guiando y marcándole la pauta para salvarlo (Cabello, 1892, p. 117), sino que, además, serán confrontados por Bello y, en muchos casos, como en el de Ofelia, culpabilizados de su desgracia ${ }^{11}$. No en balde Ofelia inaugura la segunda parte de este relato autobiográfico titulada por Bello como "La caída". En el discurso de Bello, Ofelia es representada como una suerte de femme fatale que trae consigo la ruina política del personaje: "[h]abíaseme presentado con todo el misterio y el encanto que atrae y seduce, por lo mismo que allí vemos algo desconocido que se presenta a idealizarlo" (Cabello, 1892, p. 166) ${ }^{12}$.

Bello entabla con Ofelia una pareja extramarital antifundacional, pues los une el interés por la patria, aunque desde la conspiración política, fuera del matrimonio y sin descendencia ${ }^{13}$. Además, si bien Ofelia es mostrada como un prototipo de feminidad que, en medio de su excepcionalidad (por la unión extramarital, la desvergüenza y la agenda política), no deja de cumplir el rol doméstico que se espera de ella, el personaje hace del hogar el centro de las operaciones políticas en las cuales tendrá cada vez mayor protagonismo. En tal sentido, si la mujer, desde el paradigma patriarcal, es el centro del hogar por su rol de madre y esposa (Valcárcel, 2001 , p. 18), Ofelia no es el centro de este hogarcasa de partido por su liderazgo afectivo, maternal, mariano o angelical, sino meramente político. Progresivamente, Ofelia es llamada "la Coronela Bella" (Cabello, 1892, p. 213), y no son pocos los miembros del partido que aseguran asistir a las reuniones para verla a ella, y no por adherencia al nulo proyecto político de Bello.

Ofelia emprende, dentro de sus limitaciones, un proyecto de individuación que tensiona las categorías desde las cuales podría ser vista y nombrada por la sociedad patriarcal. En primer lugar, es una extraña "madre" nacional que vive por la patria, pero no desde el centro, sino desde la conspiración, carece de descendencia y se dedica a la prostitución para poder mantener a Bello cuando este cae en desgracia y deviene prófugo de la justicia ${ }^{14}$. En segundo lugar, pese a haber sido abandonada y estafada por su esposo (un hombre poco escrupuloso que le robó para comprarse 
un título nobiliario), Ofelia no es objeto de lástima, conmiseración o de rechazo. Al contrario, se construye en torno a sí la fama de mujer inconquistable y moralmente intachable cuyo "corazón es una fortaleza que ningún asaltante ha forzado" (Cabello, 1892, p. 159), lo que la hace ser deseada por los hombres que la rodean, empezando por Bello. No obstante, cuando debe dedicarse a la prostitución para mantenerlo, Ofelia es blanco del repudio de su amante, Bello, quien prefiere regresar a la cárcel (pese a los esfuerzos que ella ha realizado para sacarlo de allí), antes que ver su golpeada virilidad un poco más magullada. A raíz de esta situación, Ofelia queda totalmente abandonada, exenta de respaldo y debe volver a la comunidad de mujeres de dudosa reputación con la que convivió antes de juntarse con Bello. En segundo lugar, la erosión del arquetipo de la madre republicana mediante el descarte de la maternidad y el matrimonio va de la mano con la contestación a los referentes intertextuales e intermediales de las "Ofelias" que, inspiradas en el personaje de Shakespeare e iconizadas en representaciones como la prerrafaelista de John Everett Millais, son representadas como bellas ahogadas y rodeadas de flores a causa de un amor desgraciado. Según Ana Peluffo (2004), las "Ofelias" fueron un motivo predilecto en la poesía modernista masculina latinoamericana y se caracterizaron por morir "at the peak of their beauty and youth" (p. 70). La hermosura y deseabilidad de estas "Ofelias" o amadas moribundas aumentaba a medida que se acentuaba su agonía, silencio e inmovilidad.

Empero, la Ofelia de Cabello se muestra como una mujer que, en el lecho de muerte, no es ni tan joven ni tan hermosa (Bello la describe como una "sombra", un "espectro", un "cadáver" - Cabello, 1892, p. 276) y, en las puertas de la muerte, se torna una moribunda habladora que se configura como el arquetipo contradiscursivo de las "amadas inmóviles", silentes y exentas de agencia del modernismo masculino. La Ofelia de Cabello adquiere lucidez y elocuencia en el momento de mayor enfermedad y es allí donde articula un discurso coherente, racional y crítico claramente alejado de la verborrea exenta de sentido de las histéricas del modernismo, o de la construcción rousseauniana de la mujer como masa precívica exenta de logos (Valcárcel, 2001, pp. 18-19). Así, a pesar de que el discurso de Ofelia se visibiliza en una etapa muy tardía de la novela, cuando llega el fin de la vida política de Bello, considero que el pronunciamiento elocuente de Ofelia no solo da cuenta de un planteamiento feminista que reitera la capacidad de ejercicio intelectual, racional y político femenino, sino que también deviene la pieza clave sin la cual no tendría sentido la autobiografía de Bello.

En contraste con las moribundas o las "Ofelias" genéricas con sus miradas perdidas, la mirada de la Ofelia de Cabello en el lecho de muerte es fija, brillante, azorada. Bello afirma que Ofelia lo interpela "con toda la lúcida fijeza de una moribunda" y, lejos de ser deseable o apacible en el tránsito a la muerte, Ofelia aprovecha los últimos soplos de vida que la acompañan durante la visita de Bello para articular un discurso agudo y elocuente lleno de verdades políticas, pese al clamor de calma y silencio por parte de Bello ${ }^{15}$ :

- Tú en tu vida pública has cometido grandes errores, y yo que hoy veo con claridad el pasado, quiero decirte algunas verdades.

\section{$[\ldots]$}

Ofelia se encontraba en uno de esos momentos de lúcida visión, de nerviosa elocuencia; una de esas ráfagas ó destellos intelectuales, que el cerebro como la luz agonizante, lanza con poderosa y extraordinaria fuerza.

\section{$[\ldots]$}

- "El amor propio, la vanidad, te han perdido; te consideraste tan grande que imaginaste que tu personalidad sería suficiente para dar vida propia y perdurable á un partido, y te equivocaste. En tus momentos de aberraciones, llegaste a creer que tus enemigos políticos eran hombres no solo de otra raza, sino también de otra especie, y también te equivocaste.

"Pretendiste ser jefe de partido y lo alcanzaste; pero ¿cuál fue el contingente que llevaste á la lucha? En política el que se presenta sin un ideal, sin un principio, es como el que va a una batalla desarmado. Se puede en el primer momento producir grande efecto, y conquistare partidarios; pero todo pasa y se evapora, como cosa sin consistencia condenada á perecer, por falta de vida

"Lo que tú fundaste no fué [sic] un partido fuerte, sólido y compacto, sino sólo una agrupación 
de especuladores, de hombres viles, que se complacían en adularte con el fin de medrar, si alcanzaban el triunfo definitivo". (Cabello, 1892, pp. 279-280)

El discurso de Ofelia, con su elocuencia, la posiciona como sujeto portador del logos, lo que le permite adentrarse en espesuras políticas que, como bien indica ella misma, serían impropias "en los labios de una mujer" (Cabello, 1892, p. 238). Es a este discurso plagado de verdades que debe contestar Bello en toda su autobiografía, como un intento fallido de justificación frente a sus fracasos. Es decir, Bello queda supeditado al espacio secundario que se le asigna tradicionalmente a la mujer con la función reproductiva y repetitiva, pues es él quien debe contestar el pronunciamiento de Ofelia, reconocer su lucidez y, asimismo, su incapacidad de respuesta. Frente a la elocuencia discursiva y la densidad ideológica del planteamiento político de Ofelia, Bello queda en el lugar del "amado inmóvil" - contraparte perfecta para el conocido poema de Nervo (Peluffo, 2004, p. 68)—, pasivo, impávido y silencioso frente al pronunciamiento y la agencia ideológica que visibiliza la moribunda habladora que es Ofelia: "[y] o no pude hablar una sola palabra; un nudo angustioso me comprimía la garganta. De pié [sic], inmóvil con las manos plegadas y el espíritu anonadado, contemplaba a Ofelia" (Cabello, 1892, p. 277).

Además, en Ofelia, la cercanía de la muerte no acentúa su belleza ni su idealidad virginal, tampoco la redime por la prostitución en la que ha debido incurrir para sobrevivir, sino que le da una "supervidencia" [sic] (p. 278) que le permite ver una serie de verdades fundamentales que la autorizan para articular un pronunciamiento político y ganarse un lugar dentro del proyecto nacional distinto al posicionamiento tradicional de la madre republicana:

En política el que se presenta sin un ideal, sin un principio, es como el que vá á una batalla desarmado. Se puede en el primer momento producir grande efecto, y conquistarse partidarios; pero todo pasa y se evapora, como cosa sin consistencia condenada á perecer por falta de vida. (Cabello, 1892, p. 280)
Adicionalmente, la elocuencia de Ofelia en las puertas de la muerte tensiona el paradigma cristiano de la confesión, ya que si bien Ofelia aprovecha este momento para hablar profusamente, no lo hace para arrepentirse por haber quebrantado el prototipo hegemónico de feminidad y el sistema de valores de su sociedad, por haber incurrido en la prostitución, por la unión extramarital ni por la participación indebida en la política ${ }^{16}$. Al contrario, se trata más bien de una confrontación de la confesión tradicional, pues en este momento final de su vida, Ofelia le dice a Bello todo aquello que calló mientras estuvo bajo el espejismo de un proyecto conjunto por el cual lo sacrificó todo y por el que se sometió a todo. Es decir, es más un pronunciamiento político que muestra una determinación y la claridad de un proyecto vital, que un mea culpa que la devuelva a la subordinación del sujeto arrepentido. Así, esta escena final la desvincula del ámbito de la pasividad y la impotencia, y la posiciona en un lugar de poder y agencia que no solo invierte la lógica de la representación tradicional de las "Ofelias" de la poesía modernista que no serían más que el "objeto" del deseo masculino (Showalter, 1985, p. 77), sino que también reitera el diálogo tensional intermedial del personaje tanto con las abundantes representaciones pictóricas de "Ofelias" románticas y prerrafaelistas, como con la Ofelia de Shakespeare, quien, como lo explican Elaine Showalter y otras críticas feministas ha sido silenciada e invisibilizada en los estudios críticos posteriores ${ }^{17}$.

\section{Pasajes sumergidos: pactos femeninos y feminismos radicales desde un ideario romántico sentimental}

Incurables, de la escritora judío-venezolana Virginia Gil de Hermoso (1905), es un relato con fuertes marcas romántico-sentimentales centrado en un amor imposible que lleva a sus protagonistas a la muerte. El texto está focalizado en el personaje de Margarita, una huérfana con alma de artista que es criada por su tía Ángela, una madre viuda que le brinda a Margarita todos los cuidados necesarios, en medio de sus penurias económicas. La relación entre Margarita, doña Ángela y su hija Elina es de fraternidad y armonía absoluta, hasta que reciben la visita de su primo Reinaldo, joven artista que 
emprende el viaje transatlántico inverso (de España a Venezuela), para buscar inspiración estética. Reinaldo despierta el amor en ambas primas y da claras señas de corresponder a Margarita. El potencial proyecto amoroso entre Reinaldo y Margarita contraviene los planes de doña Ángela, cuya maternidad se encuadra en el tipo de feminidad burguesa que tiene como proyecto ético-vital dejar arreglados los destinos de sus hijas mediante el matrimonio: "[1] as casaré muy bien; este es mi sueño; ver a mi hija casada y feliz y que no me la dejen pasar trabajos; este es mi primer deber; sobre el mundo entero, mi hija" (Gil de Hermoso, 1905, p. 4). Empero, al constatar el enamoramiento entre los jóvenes equivocados, doña Ángela enferma de gravedad y, en esa efimera convalecencia, hace jurar a Margarita no entrometerse en el matrimonio pactado entre Reinaldo y Elina. Margarita acepta la petición de su tía y se dedica a velar por la recuperación de su benefactora (Gil de Hermoso, 1905, p. 30).

En línea con el ideario romántico-sentimental en el que se enmarca la novela, la voz narrativa plantea, en primera instancia, la renuncia de Margarita como una reiteración de las cualidades marianas del personaje, de su abnegación y su capacidad de entrega a los otros:

- ¡Ay Dios! Vivid o morid tranquila que, aun a costa de la mía, haré la felicidad de Elina.

La joven parecía transfigurada; tenía en su actitud la silueta delicada y dolorosa de aquellas vírgenes cristianas que inclinaban la frente para recibir la corona del martirio. (Gil de Hermoso, 1905, p. 27)

Sin embargo, la misma voz narrativa también deja entrever en la actitud de Margarita la manifestación de una decisión, una agencia y, en tal sentido, una voluntad férrea impensable e inefable para un sujeto atravesado por su condición sociosexual: mujer y huérfana cuya vida habría de estar supeditada a las voluntades de los otros. De esta forma, la novela va resignificando y politizando con sutileza la retórica tradicional del despolitizado sacrificio femenino exigido por la sociedad patriarcal y lo convierte más bien en el punto de anclaje para la agencia y la rebelión soterrada desde el pacto entre mujeres:
Almas como las de Margarita no vacilan, aunque se rompan en las recias sacudidas de la tormenta; esas almas se adelantan a la lucha como para encontrar en el combate el fin que presienten.

Ella acercó a sus labios el amarguísimo cáliz de lágrimas, ¡vaciló y dudó!... ¡se sentía tan amada!... pero al fin la frente ya serena para siempre, y dijo:

¡Más amargo sería el remordimiento! ¡Viva mi tía!... jsea Elina feliz, aunque vaya yo a morir como las algas en el fondo del mar!... jamor mío! ¡queda en mi corazón y ni mis ojos, ni mis labios te delatarán jamás! (Gil de Hermoso, 1905, pp. 28-29)

En primer lugar, el personaje se desmarca del imperativo sentimental consciente de la deuda que ha contraído, de manera que el pacto entre mujeres está por encima de cualquier arrebato emocional. Esta racionalidad confronta las representaciones patriarcales tradicionales del sujeto femenino como pura emoción acrítica siempre requerida de la ventriloquización y siempre transparente para la interpretación masculina. Margarita muestra su determinación al evitar que los demás perciban su angustia, al lograr negar efectivamente su afectividad y sentimentalidad (son frecuentes en Margarita expresiones como "no siento nada" -Gil de Hermoso, 1905, p. 13) y al reiterar su compromiso tanto con su tía, como con Elina, las dos mujeres que la han salvado de la desgracia ${ }^{18}$. En tal sentido, el texto muestra, como puede verse en obras de otras autoras del período, la imposibilidad de un proyecto sentimental de corte melodramático tradicional (la historia típica de joven desvalida que termina siendo elegida por el joven privilegiado), en un contexto en el cual las mujeres deben pagar deudas vitales sin contar con más recursos que los pactos y las redes sororales que establezcan entre ellas ${ }^{19}$. Asimismo, la voluntad del personaje se revela en el momento en que, ante la conciencia de la imposibilidad de concretar su deseo inicial de casarse con el joven amado, rechaza también el matrimonio de consuelo con Gustavo, el cual habría sido acordado por su tía. De esa forma, Margarita se singulariza al ejercer una resistencia, que, aunque sea mediante la enfermedad inducida por la inanición, le 
permite evadir los destinos burgueses tradicionales del matrimonio sin amor y los hijos indeseados (Gil de Hermoso, 1905, p. 12). Margarita escoge para sí un desenlace con fuertes connotaciones intermediales, como el de las Ofelias que mueren "como las algas al fondo del mar" (Gil de Hermoso, 1905, pp. 2829). Empero, se trata una vez más de una dislocación ideológica y semántica, ya que ese trayecto vital es una elección y no una consecuencia o victimización, sino una autoconstrucción artística que parte de un referente estético-ideológico (el de las bellas muertas) resignificado en tanto dotado de agencia ${ }^{20}$.

La voz narrativa resalta la determinación de Margarita, su heroicidad, su sentido del honor y obligación. Así, la escena de la renuncia a Reinaldo resulta un pasaje fundacional en el que no solo se visibilizan los cambios emocionales (el paso del mandato parental a la obligación contraída), sino también el devenir de Margarita como sujeto activo y con agencia que pacta, que establece acuerdos, en lugar de ser pactado por los otros. Este gesto muestra cómo desde la literatura, y desde un texto enmarcado en una ideología burguesa-sentimental en apariencia tradicional, se abre la posibilidad de un imaginario impensable en otros ámbitos, como la filosofía y la antropología, donde, como lo explica Celia Amorós, las mujeres carecen de total agencia porque sus vidas son negociadas y pactadas por los varones (2005b, p. 20). Acá son las mujeres, desde las redes que establecen entre ellas, las que determinan sus destinos vitales $-\mathrm{O}$ sus resistencias-.

En su proyecto de individuación, Margarita se deslinda de los modelos genéricos de feminidades (la huérfana, la abandonada, la malcasada) y, a su vez, resignifica los imaginarios hegemónicos de lo femenino, pues esta individuación se articula desde una aparente intensificación de los valores de la domesticidad y el sacrificio. De esta forma, se entrega al cuidado del hogar y a los rezos, pero ese encierro doméstico la acerca a un imaginario de ángel del hogar extrañado, sin matrimonio y sin descendencia. Margarita hace de este espacio una versión alterada y dislocada de la torre de marfil modernista, en tanto es el lugar desde el cual emprende un evangelio del yo para su construcción como ideal de vida ascética y estética:
Mientras tanto, la pobre huérfana, libre de todo disimulo, se entregaba a sus intimas tristezas; vertió todas las lágrimas que oprimían su corazón y con profunda melancolía recorrió el campo desolado de sus esperanzas: fortalecida por aquel desahogo, encontraría nuevas fuerzas para la lucha interior, que era su más penoso trabajo. (Gil de Hermoso, 1905, p. 50)

Asimismo, Margarita resignifica y politiza su misma caracterización como mártir. En tal sentido aprovecha el ámbito doméstico, el cual debería ser el espacio de anulación de sí misma para los otros, para ejercer una serie de reclamos que dan cuenta del despliegue de su subjetividad diferencial y en resistencia. De ese modo, la entrega y la espiritualidad del personaje son resignificadas y reencauzadas hacia la demostración de su agencia y el emprendimiento de un proyecto egotista que entabla un extrañado diálogo con los paradigmas del modernismo patriarcal:

Margarita al llegar a su cuarto se hundió en el lecho; los sollozos la ahogaban.

- ¡Será un sueño! ¡Me parece estar bajo el sopor de una pesadilla! ¡Elina enamorada de Reinaldo y mi tía exige su dicha!... iy yo!... iy yo, desdichada que le adoro y me siento amada! ¡Jesús mío! (Gil de Hermoso, 1905, p. 28)

El uso del discurso religioso utilizado para el proyecto egotista que hace expreso el reclamo por el "yo" abre una vertiente para comprender las sensibilidades alternativas del entresiglos, las cuales se articularon en muchos casos a partir de la redefinición de los arquetipos de la enfermedad femenina romántica ${ }^{21}$. Igualmente, el diálogo con el modernismo-decadentista radica en la apropiación de la religiosidad como estrategia de resignificación, dislocación y autoinscripción ético-estética. Tal como lo explica Rafael Gutiérrez Girardot - aunque en referencia al modernismo masculino y no a las demás estéticas-ideologías del entresiglos - la apropiación del ideario religioso y, sobre todo, místico, es uno de los recursos a los que apelaron los artistas del período para inscribirse a sí mismos en tanto yo, singularizados y desencontrados frente al contexto. Se trata de una "mundanización" de la vida, una "desmiraculización" del mundo", que va de la mano con la "sacralización 
que se manifiesta en los 'principios de fe' con los que se asumieron la ciencia, el arte, el progreso" (Gutiérrez Girardot, 1988, p. 50).

Así, Margarita se ampara en el motivo de la confesión cristiana a las puertas de la muerte para reafirmar esta agenda egotista que consiste en su ejercicio elocuente de discurso en ese momento supremo que, paradójicamente, no deja de dilatarse. Si bien esta "confesión" no busca sino decir "todo lo que [tiene] dentro del alma" (Gil de Hermoso, 1905, p. 105); estas palabras, en boca de Margarita, tendrán tanto el formato como el efecto contrario al asociado al sacramento religioso de la confesión en el último soplo de vida porque, en su caso, Margarita alude a los gritos de dolor que, en ese momento, ha decidido no seguir silenciando. Por ende, su confesión no trae paz sino turbación, ya que Margarita anuncia que su sufrimiento será la sombra para la felicidad de los que la rodean y la escuchan con devoción y admiración:

- Como voy a guardar dentro de poco tiempo un eterno silencio, dejadme deciros, ahora que sabéis de qué mal voy a morir todo lo que tengo dentro del alma. Conservad, vos a quien tanto he amado, una memoria larga y triste de mi vida: sólo en el seno de la muerte hago esta confesión suprema; ;ay! yo debiera morir sin que mis gritos de dolor os hubieran hecho conocer el estado de mi corazón, pero la fatalidad lo ha dispuesto de otro modo; perdonadme si de hoy más mi pálida sombra va a turbar la claridad de vuestra dicha. (Gil de Hermoso, 1905, p. 105)

Del mismo modo, el texto disloca semántica e ideológicamente el arquetipo de la bella enferma, pues Margarita no será una enferma silente, sino que, al contrario, en la situación de la convalecencia articula largos discursos que la convierten en otra variante de las moribundas habladoras presentadas por las escritoras del entresiglos en sus contestaciones a los arquetipos modernistas de lo femenino. Margarita no solo confronta las representaciones de las "Ofelias" silentes, inmóviles y sin agencia, sino que aprovecha esas últimas gotas de aliento para articular un discurso en el que se confiere a sí misma el lugar de artista y sujeto creador de universos y destinos. Margarita nombra su concesión ante Elina como la gran obra de su vida y exige sea preservada:
- ¡Adiós! - le dijo; - no destruyáis mi obra... la felicidad de Elina... después... que ya esté helada... recoged de mi pecho... este crucifijo... que tanto... he besado... y a quien he pedido... fuerzas para... dejaros... Amad a Gustavo... en memoria mía... consolaos... sin olvidarme... voy a esperaros... allá en el país... de las recompensas. (Gil de Hermoso, 1905, p. 112)

Llama la atención cómo este gesto de Margarita dialoga tensionalmente con el de las masculinidades modernistas-decadentistas. Esa felicidad (obra) que ella supuestamente crea para su prima no es sino una idea, una construcción subjetiva con connotaciones totalitarias. La vida de Elina está constantemente en un estado de suspensión derivado de la larguísima convalecencia de Margarita, quien deviene sujeto de adoración para todos los que la rodean. Ahora bien, frente a las narrativas de corte sentimental que ubican la felicidad femenina en las manos masculinas con esta escena del texto, la novela vislumbra una posibilidad otra donde la mujer puede adquirir y ejercer poder a través de acciones, decisiones y pactos realizados en las grietas del patriarcado. Estas grietas le permiten actuar como sujeto y agente de creación de realidad, tanto para ella, como para Elina y su tía. Alterando los mandatos patriarcales, los que devienen objetos pactados en la novela son, paradójicamente, los sujetos masculinos; en tal sentido, las vidas de Reinaldo, Gustavo y el Sr. Frinkler (el padre de Gustavo) girarán en torno a las acciones y voliciones de Margarita, sobre todo en su situación de convalecencia.

Asimismo, en diálogo con la Ofelia de Cabello, Margarita no solo descarta la maternidad, sino también extraña el modelo de la bella muerta, pues, cuando se describe al personaje en sus últimos soplos de vida, la voz narrativa refiere que estaba hermosa "[a] pesar de los reflejos pálidos de la muerte" (Gil de Hermoso, 1905, p. 113). La muerte no es el momento climático de la belleza, sino que más bien puede ir en detrimento de ella. De igual forma, es relevante que la elocuencia de Margarita como moribunda habladora deje a Reinaldo en el lugar de la inmovilidad, el silencio y la confusión mental, impensables para un sujeto masculino que habría de detentar la lucidez y la claridad del artista:

A pesar de los reflejos pálidos de la muerte, [Margarita] tenía el mismo encanto que en vida 
hacía superior su belleza. Reinaldo, inmóvil en la puerta contemplaba el cadáver mudo de desesperación. Los recuerdos se amontonaban en su mente como las nubes en una atmosfera tempestuosa. (Gil de Hermoso, 1905, p. 113)22

Por último, mientras las representaciones de las bellas muertas modernistas — desde el modernismo patriarcal - las muestran en el rol pasivo e impotente de la mujer que da su vida ante la imposibilidad de concretar su unión con el hombre al que amaba; en Incurables, la muerte de Margarita, moribunda habladora y con agencia es la que deja a Reinaldo vacío, exento de sentido. Reinaldo pasa así a ocupar la posición tradicional del sujeto femenino que pierde la razón de vivir tras la muerte del amado. La muerte de Reinaldo después del fallecimiento de Margarita visibiliza la posibilidad de un pacto de igualdad y comunión ético-estética entre un hombre y una mujer, impensable tanto desde la lógica de Rousseau (cfr. 2019) y el lugar que le asigna a la mujer en sus discursos fundacionales para la sociedad moderna occidental, como para el artista modernista en general.

Retomando y resignificando una tradición literaria romántico-sentimental, Incurables representa una versión extrañada de la mujer-bella enferma y ángel del hogar que, como ha sido evidenciado en mi lectura, tensiona todos los imaginarios patriarcales impuestos al sujeto femenino; se desvincula del modelo de enunciación de la madre republicana (aunque, en sus paratextos, indique la dedicatoria del texto a un hijo muerto y aclare la ausencia de pretensiones estéticas - Gil de Hermoso, 1905, p. $2)^{23}$, y abre un pasaje para imaginar otras formas de agencia e igualdad para la mujer desde la paradojal intensificación de los roles más tradicionales.

\section{Belleza, erotismo y vitalidad: contestaciones a la idealización de la enfermedad femenina en La rosa muerta}

La rosa muerta, publicada por la escritora peruana Aurora Cáceres en 1914, presenta un proyecto de singularización ético-estética de un personaje femenino que se rebelará tanto frente al paradigma de la mujer burguesa mediante su rechazo al matrimonio, la sentimentalidad, la domesticidad (y su entrega a la adoración de la belleza de su cuerpo), como frente a los idearios modernistas patriarcales de lo femenino. $\mathrm{Al}$ inicio del relato, la voz narrativa refiere cómo el personaje se enfoca en el cuidado del cuerpo y el gusto por la moda, mientras manifiesta un profundo rechazo al matrimonio y al amor sentimental (lo que le era posible dada su viudez y su situación económicamente holgada):

[Laura] amaba su cuerpo como se ama lo bello y cual una pagana le consagraba culto; con gran esmero estudió la estética del movimiento, de la flexibilidad de la línea, y los ejercicios corporales, que practicaba diariamente bajo la dirección de un hábil gimnasta. No obstante, solía experimentar cuando se presentaba ante su vista una pareja de enamorados cierto recrudecimiento sentimental parecido a un despertar epiléptico; una sensación interna de escalofrío, como de invierno que paraliza la vida; una crispación epidérmica que se prolongaba mucho tiempo, hasta que, súbitamente, dominaba su emoción. (Cáceres, 2007,p. 8)

Laura, una mujer joven y viuda, de posición social acomodada, lleva una vida activa de salones, reuniones y contemplación estética, hasta el momento en que es afectada por una condición patológica desromantizada ${ }^{24}$. Un cáncer de ovarios, en lugar de la tuberculosis tradicional, aqueja a esta mujer y amenaza con deformar su cuerpo de Venus (referente con el que ella siempre se emparentaba) y, sobre todo, limitar su libertad de acción y movimiento ${ }^{25}$. En tal sentido, Laura se desmarcará de las construcciones patriarcales de lo femenino tanto desde el modernismo, con una enfermedad que no estetiza ni hace ideal, sino que deforma, limita y la hace un cuerpo genérico de mujer enferma; como desde el ideario burgués liberal al confrontar la imagen de la madre republicana o la mujer ángel del hogar que es pura sentimentalidad y sacrificio. Al contrario, la voz narrativa la describe de manera tal que se acercaría a la tipificación de la figura del dandi decadentista en su variante - extrañada - femenina: frívola e insensible, sin ambiciones maritales ni reproductivas y enfocada exclusivamente en el goce estético que producía en ella llevar trajes de moda sobre su cuerpo:

Frívola con arte y graciosa cual una muñeca, sin sensibilidad, su existencia entera la consagraba a mantener el prestigio de estar de moda, 
deslumbrando por el gusto artístico y exótico de sus vestidos. Si algunas veces despertaba pasiones, correspondía con sonrisas, con miradas, y desde el momento que un hombre principiaba a requebrarla con tenacidad y que creía ver en él a un amoroso apasionado, se apoderaba de su espíritu tal disgusto, que cortaba con él toda amistad, y del importuno enamorado huía, evitando hasta el encontrarle. (Cáceres, 2007, p. 7) 26 $^{26}$

Por sus ventajas sociales y por el contexto en el que se desarrolla la novela, el personaje, Laura aspira a una vida distinta en la que el proyecto sentimental y maternal no es el fin último de la realización femenina, sino más bien un obstáculo para el tipo de proyecto vital que emprende consigo misma. De esta manera, es tan antiburguesa como las masculinidades prototípicas del ideario modernista-decadentista, pues incluso el aspecto de la moda, que bien pudiera leerse como una marca del consumismo típico de las mujeres burguesas del período, es para Laura una vía de entrada a una modernidad de la cual las mujeres, como explica Rita Felski (1995), han sido excluidas ${ }^{27}$. Empero, es necesario destacar que la insensibilidad del personaje es, sobre todo, en un plano sentimental (lo que reitera su condición contraria a la de las feminidades hegemónicas burguesas), ya que el personaje sí sufre y padece dolor, no solo físico, sino también estético. Laura, como el artista modernista, vive por y para la belleza y padece con angustia la fealdad, lo que reafirma tanto su intelectualidad, como su singularidad, reflejadas también en su capacidad de contestación y desobediencia:

La única persona que sufría, la única angustiada, la única que cerraba los ojos para no ver este cuadro de depravación estética era Laura; en cambio todos los concurrentes la miraban, la miraban con asombro. Solo ella se mostraba rebelde, conservando presto su abrigo y su sombrero, era la mujer que no obedece y que se subleva contra la orden del facultativo, según la cual toda paciente debía desvestirse en el vestíbulo de la casa. (Cáceres, 2007, p. 12)

Asimismo, la vinculación constante del personaje con el referente de Venus implica su inserción dentro de un paradigma erotizado y fundacional que la aleja de los modelos de las vírgenes moribundas o las mujeres modélicas de la virtud doméstica. Esto se refleja con mayor contundencia en el momento en que Laura se enfrenta con la verdad de su enfermedad, noticia que vive con profundo miedo y dolor, mas, sobre todo, con inquebrantable agencia y decisión. Mientras la literatura romántico-sentimental y la modernistadecadentista masculina convergen en mostrar a las mujeres enfermas como paradigma de idealidad y belleza, pero también de silencio y vulnerabilidad; Laura asume frente a la enfermedad una actitud que la distancia radicalmente del modelo de la bella enferma inmóvil, virginal y totalmente supeditada a la autoridad masculina. En la enfermedad, Laura será ágil, proactiva y decidida en la búsqueda de una cura para su mal (promesa incumplida por la ciencia ${ }^{28}$ y, además, ejercerá un erotismo inusitado e incomprensible en tanto no encaja ni dentro de los paradigmas de la mujer modélica de la virtud doméstica, ni en el de la bella virgen moribunda, ni en el de la femme fatale.

En primer lugar, mientras busca una cura para el antiestético cáncer en el sistema reproductivo, Laura recorre los consultorios de distintos médicos en un tránsito que la voz narrativa denomina una "excursión dolorosa", una peregrinación (Cáceres, 2007, p. 2). Esto vislumbra otra variante del misticismo secularizado del entresiglos, una forma de profanación que dialoga con las explicadas por Rafael Gutiérrez Girardot en sus reflexiones sobre el modernismo y el complejo diálogo con la modernidad, aunque es radicalmente distinta tanto a la que emprende la Margarita de Incurables, como la de los personajes modernistas-decadentistas. El recorrido de Laura no es ni espiritual-ascético, como el de Margarita, ni de pérdida en el vicio o los placeres en búsqueda de alguna sensación última, como en el caso de textos modernistas como el del mismo Enrique Gómez Carrillo $^{29}$. En Laura, la peregrinación se da en busca de respuesta para una enfermedad que no es vivida intelectualmente, sino físicamente; un padecimiento que no la singulariza y la hace un ideal estético, sino que amenaza con deformarla, quitarle su vida, libertad e individualidad al tornarla un cuerpo-masa más definido a partir de una condición patológica concreta (no ideológica ni intelectual).

Como muestra de su ser moderno y su agencia, Laura se comporta frente a los médicos como una 
cliente que tiene la autoridad para elegir al médico que ha de tratarla y, sobre todo, para exigir un trato ético-estético que no la reduzca a un genérico cuerpo enfermo, como los que estaban en las salas de espera de los consultorios médicos que visitaba (Cáceres, 2007, pp. 11-12 $)^{30}$. De esa forma, Laura desestabiliza el saber-poder médico patriarcal (LaGreca, 2012, p. 625), ya que se presenta como mujer bella y enferma con una agencia y una elocuencia impensable para las bellas enfermas del modernismo masculino ${ }^{31}$. Laura intenta ejercer su libertad no solo mediante sus acciones, sino a través de la toma de decisiones que le permitan un tipo de vida determinado.

Es con el doctor Castel, de ascendencia oriental y manos cálidas, que Laura siente que recibe el trato que desea, el de un doctor que ve en ella, antes que una enferma, una mujer bella. Laura y Castel entablan una relación erótica extramarital (Castel era casado), que reemplaza por momentos la relación médico-paciente aborrecida por Laura. Cuando su enfermedad llega a un punto crítico debido a las relaciones que mantiene (y que, por mandato médico, debía evitar), Laura no espera ser salvada por Castel, sino que se va a Alemania para experimentar una muerte tan antiestética como los consultorios que allí visitó ${ }^{32}$. Esto termina de desplazar a Castel de su condición de médico y reducirlo simplemente al lugar del amante impotente.

En su estudio sobre el texto, Elena Grau-Lleveria (2018) señala que la principal contestación al ideario modernista patriarcal que articula La rosa muerta radica en la confrontación a la representación estetizada de la enfermedad femenina típica desde el modernismo masculino (p. 38). A través de Laura, el texto muestra la enfermedad en términos de deformación y fealdad, por lo que, como señala la crítica "[e]l horror de la enfermedad para Laura no está en la potencial muerte que esta pueda causarle, sino en los efectos de fealdad que se mostrarán en su cuerpo" (GrauLleveria, 2018, p. 38). De hecho, es significativa la mirada que ejerce Laura sobre los cuerpos enfermos de las mujeres que esperaban ser vistas por los médicos en los consultorios que visitaba, cuerpos genéricos de las mujeres desindividualizadas frente a los cuales ella intenta desmarcarse por percibirlos como los protagonistas de un "cuadro de depravación estética" (Cáceres, 2007, p. 12).
Rebelándose contra las visiones hegemónicas de la mujer enferma desde la mirada de los especialistas, Laura se vincula a sí misma con el referente de una Venus que encuentra y reafirma su vitalidad en el erotismo; empero, no se trata de un erotismo que la acerca al arquetipo de la femme fatale, sino que es un erotismo intelectualizado que, además, restituye eso que habría sido silenciado o estigmatizado desde ciertos idearios patriarcales de la modernidad liberal, a saber, el orgasmo femenino ${ }^{33}$. Según Thomas Laqueur, las referencias al orgasmo femenino habrían sido explícitas y profusas en los manuales medievales para las comadronas, donde el orgasmo era visto como un aliado fundamental para la fecundidad (1990, p. 9). En La rosa muerta se alude al orgasmo femenino, pero no como aliado de una maternidad imposible en el texto, debido a las condiciones médicas de Laura, sino como manifestación de una sexualidad insatisfactoria para el sujeto femenino que desea experimentar, en medio de su sufrimiento, alguna sensación que la reconecte con el placer y la vitalidad que están bajo amenaza. Asimismo, confrontando la desintelectualización de la femme fatale que es pura corporalidad, la experiencia erótica en Laura se vive en términos intelectuales. Laura no puede alcanzar el orgasmo porque el espacio - el consultorio del doctor - no era un lugar acorde para el clímax. Entretanto, la figura del médico es caricaturizada en tanto el doctor, paradigma de la racionalidad, se muestra desbordado por el deseo y el instinto, a pesar de lo inapropiado del ambiente para un encuentro erótico:

La actitud de Laura, durante la realidad del amor, fue de abnegación. Una hilera de vasos de cristales blancos que contenían ellíquido, color del topacio, que debía ser analizado posteriormente por el doctor, justamente se encontraban colocados al frente de ella, y sus ojos, sin poder evitarlo, miraban el líquido segregado por los enfermos. Esta visión impidióle concretar sus sentidos y sentir el espasmo supremo. (Cáceres, 2007, p. 54)

Laura contesta las representaciones tradicionales desde el ideario patriarcal de la mujer erótica como una fermme fatale que es solo instinto, corporalidad y potencial destructor (con imágenes típicas como las "vaginas dentadas" o ninfómanas) ${ }^{34}$. Además, la escena 
le sirve a la autora para introducir otra dislocación semántica en el imaginario hegemónico sobre lo femenino al explicar que Laura vive el encuentro sexual insatisfactorio en clave de abnegación. Llamar abnegación a la renuncia al placer por parte de Laura constituye un gesto disruptivo en la novela, ya que disloca la matriz ideológica del sacrificio femeninomariano y la usa para aludir al precio que Laura está dispuesta a pagar para recibir de Castel la imagen que desea tener de sí misma durante la relación erótica.

El punto climático de la rebelión de Laura frente a las imágenes arquetípicas de lo femenino tiene lugar cuando intenta imponerse como ideal estético vivo y vital (en contraposición con la tendencia a idealizar "Ofelias" moribundas o "rosas muertas", Grau-Lleveria, 2018, p. 38) ${ }^{35}$, mediante la fijación de su imagen en una pintura elaborada por un reconocido artista contemporáneo que afirmaría que el desnudo de Laura habría sido la base para la representación de "la Venus más perfecta que queda del arte contemporáneo" (Cáceres, 2007, p. 66). Configurándose como moribunda escribidora, Laura aprovecha sus últimos soplos de via para redactar una carta a Castel donde da las pautas sobre cómo ha de ser vista y recordada: destruirlo. De hecho, su plasmación artística vital, "cuadro testamento" según Grau-Lleveria (2018, p. 40), es una manifestación del poder que ella ha ejercido sobre el médico al imponer su visión de su cuerpo y de sí misma y su autoconstrucción artística, en contestación al referente polémico que constituyen las feas pacientes de los consultorios médicos visitados en Berlín.

Así, la rebelión que plantea La rosa muerta frente a las inscripciones patriarcales de la mujer es múltiple. Se refiere tanto a su desvinculación del prototipo de la mujer burguesa por su rechazo a la domesticidad y la maternidad, al igual que por su gusto por el arte improductivo y el cuidado de su cuerpo, como a la contestación de la construcción modernista-decadentista patriarcal de la mujer enferma al confrontar el embellecimiento de la patología femenina y presentarla más bien en clave de deformación. De la misma forma, la enfermedad y la cercanía de la muerte le dan a Laura la posibilidad de ejercer una subjetividad, una agencia y una elocuencia que la colocan en un mismo nivel de diálogo con las masculinidades y que, por ende, la alejan tanto de la condición genérica femenina burguesa, y del colectivo de "mujeres" con el cual nunca va a identificarse, en tanto "egoísta" (Grau-Lleveria, 2008, p. 52)36, como

\section{Laura contesta las representaciones tradicionales desde el ideario patriareal de la mujer erótica como una femme fatale que es solo instinto, corporalidad y potencial des- tructor (con imágenes típicas como las "vaginas dentadas” o ninfómanas)}

\begin{abstract}
Si fatigado tu espíritu del espectáculo del desnudo enfermo, quieres recordarme, ve al estudio del pintor X; él, que siempre pintó mujeres vestidas que se abrasan de sensualismo, con la maestría de su pincel incomparable, ha hecho mi retrato, desnuda. No te espantes, es un desnudo casto. Será la Venus más perfecta que queda del arte contemporáneo, asegura el artista. (Cáceres, 2007, p. 66)
\end{abstract}

La elocuencia de Laura, tanto en su enfermedad como al final de su vida, le permitirá organizar las representaciones y los sentidos que se proponen desde el discurso hegemónico, personalizado en el texto por Castel y los demás médicos con los que interactúa durante su peregrinaje en busca de alguna receta para salvar su cuerpo de la enfermedad que amenaza con de las imágenes de las bellas enfermas o bellas muertas del modernismo masculino.

Del mismo modo, en diálogo con las propuestas anteriores, el texto se caracteriza por descartar la maternidad y el imperativo de la reproducción, pues es más bien el artista masculino el que es ubicado en el lugar de la reproducción de un ideal estético basado en una mujer real que, en el caso de Laura, se celebra en sus condición vital y erótica, no lánguida, impávida y moribunda. Recordemos que Laura, en su lecho de muerte, indica al artista el tipo de representación estética que ha de hacer de ella misma, con lo que se resiste a los típicos cuadros post mortem o los que, como muchas representaciones visuales del período, estetizan la enfermedad femenina ${ }^{37}$. Laura se deleita en que la imagen que han hecho de ella 


\section{Estas autoras resignifican tales modelos de feminidad y los repolitizan mediante la crea- ción de personajes con capacidad de subjetivación individualizadora, agencia y discurso.}

la retrata desnuda, como una Venus contemporánea desvinculada de modelos ideales y, más bien, mostrada como la mujer real, erótica, vital, es decir, como la imagen de sí misma con la cual quiere ser recordada. Ante la elocuente carta de Laura, Castel queda reducido a un cuerpo exánime, sin pensamiento ni voz (Cáceres, 2007, p. 66). Es decir, el personaje deviene otra variante del "amado inmóvil" y enmudecido que habría sido tan celebrado en su versión femenina por parte de los artistas modernistas-decadentistas pero que, en este caso, resulta subversivo y contestatario al reducir al hombre-médico-amante a la impotencia.

\section{A manera de conclusión}

Los tres textos aquí presentados muestran personajes femeninos que convergen en exponer facetas otras de la enfermedad femenina que las desvinculan tanto del ideario naturalista que ve en la patología un indicio de degeneración, como de las clásicas representaciones idealizadas de la enfermedad desde la matriz ideológica modernista-decadentista. En estos textos, la enfermedad es confrontada en su realidad más descarnada para la mujer: como algo que afea, afecta, deforma - en los casos de la Ofelia de El Conspirador o la Laura de La rosa muerta - o que resulta la única vía de escape para la feminidad que quiere una vida distinta, alejada de la maternidad, negada a la sentimentalidad, pero que carece de las condiciones sociales y materiales para lograrlo - como en el caso de IncurablesEn tal sentido, dichos personajes no solo muestran imaginarios de lo femenino que se desvinculan del paradigma de virtud doméstica y nacionalmente comprometida de la "madre republicana", o del muy burgués "ángel del hogar", sino que presentan otra vertiente de la enfermedad como crítica a una sociedad y a una modernidad fallidas en tanto las ha dejado por fuera. Laura muere por los límites de la ciencia, Ofelia se enferma a causa de la mala vida a la que la empuja la miseria y Margarita no tiene otra alternativa que enfermar para salir del espaciotiempo burgués del mercado marital y de los hijos indeseados. $\mathrm{Al}$ mismo tiempo, nuestros personajes se emancipan respecto a las representaciones patriarcales tradicionales de la enfermedad femenina. Frente a las construcciones de bellas enfermas o muertas silente, inmóviles, como las "Ofelias" de la poesía modernista latinoamericana masculina, estas mujeres, en la enfermedad, devienen variantes de moribundas habladoras, elocuentes, lúcidas, con logos y, sobre todo, con capacidad de acción, de decisión y de agencia. En consecuencia, los textos abordados dejan entrever las contestaciones progresivas que las escritoras del período articulan frente a las propuestas estéticoideológicas del modernismo-decadentismo, corriente predominantemente masculina que, al admitir como únicas representaciones de la mujer las bellas muertas inmóviles o las femme fatales, niegan la posibilidad de un sujeto mujer artista o intelectual. Estas autoras resignifican tales modelos de feminidad y los repolitizan mediante la creación de personajes con capacidad de subjetivación individualizadora, agencia y discurso.

Asimismo, la contestación al orden burgués permite comprender otras dimensiones de las rebeliones emprendidas por estos personajes que convergen en su cuestionamiento tácito a la maternidad. Por un lado, las protagonistas de estas novelas muestran la posibilidad de una realización individual que no radica en la función reproductiva y, por la otra, el rechazo o la mera imposibilidad de la maternidad va anunciando, sobre todo en los casos de El Conspirador e Incurables, una contestación radical al sistema capitalista y la modernidad fallida, la cual le impone al sujeto femenino la responsabilidad de la (re)producción de una fuerza de trabajo (los hijos) sin que ellas sean reconocidas como piezas claves del engranaje productivo (Federici, p. 23) ${ }^{38}$. De esta manera, los personajes femeninos que protagonizan estos relatos se ubican en una esfera de improductividad para el sistema que las posiciona en un interesante nivel de diálogo tensional con los artistas modernistas masculinos que, en su momento, apelaron a la no productividad económica del trabajo artístico como una forma de resistencia al sistema mercantil que denunciaba la falta de valor económico del arte; solo 
que, en este caso, tales personajes femeninos hacen de su trayecto vital singular su acto de construcción o resistencia-ético-estética.

Los textos aquí analizados constituyen puntos de fuga para los imaginarios de lo femenino desde el repertorio de posibilidades pensado y provisto por los órdenes estético-ideológicos dominantes. La lectura en red de estas obras crea las condiciones de posibilidad para una valoración distinta de la producción literaria y cultural del período de entresiglos que no se limite a las obras de los autores masculinos y los imaginarios sociosexuales propuestos por las mismas, sino que arroje luces sobre eso que Michel Foucault ha denominado los "saberes sometidos", es decir, los saberes "discontinuos, descalificados, no legitimados" que atentan "contra la instancia teórica unitaria que pretende filtrarlos, jerarquizarlos, ordenarlos en nombre de un conocimiento verdadero" (2001, p. $22)$. Se trata de grietas al sistema que permiten ver las contestaciones y resignificaciones articuladas por las autoras, en distintos momentos y contextos, frente a los paradigmas estético-ideológicos y culturales dominantes, empero, silenciados debido a los sistemas de verdad e invisibilización impuestos por los mismos procesos de canonización (Pratt, 1998, p. 87). Así, estas fisuras pueden crear pasajes para otras aproximaciones a la historia literariocultural hispanoamericana y, sobre todo, para el ingreso de voces otras y de imaginarios sociosexuales alternativos a una modernidad entendida en términos patriarcales.

\section{Notas}

1 Esta investigación fue financiada por la Universidad Nacional Mayor de San Marcos, Resolución Rectoral n. ${ }^{\circ}$ 01686-R-20, con código de proyecto E20030271.

2 Según Bonnie Frederick (2006), Harriet Beecher Stowe -referente clave para las escritoras latinoamericanas del siglo XIX- logra conjugar los imaginarios de lo "ultrafemenino" desde el paradigma patriarcal con el rol escriturario y, de esa forma, crea las condiciones de posibilidad para su legitimidad, autoridad y, sobre todo, su inserción dentro de un imaginario nacional del cual había sido excluida. La madre republicana representó, para muchas autoras, la posibilidad de un "rol nacional sin sacrificar su voz única y femenina" (p. 102; traducción propia). Entre los estudios críticos que han analizado los usos estratégicos de los imaginarios patriarcales de lo femenino para vehiculizar una agencia dentro de espacios no tradicionalmente masculinos están los trabajos fundacionales de Josefina Ludmer, con el análisis de las paradigmáticas estrategias de Sor Juana Inés de la Cruz para legitimarse intelectualmente en "Las tretas del débil" (1985); Jean Franco (Plotting Women, 1989); Francine Masiello (Between Civilization and Barbarism, 1992); Francesca Denegri (El abanico y la cigarrera, 2004 [1996]); Joan Torres-Pou (El e[x]terno femenino, 1998); Mary Louise Pratt ("Don't Interrupt Me: the Gender Essay as Conversation and Countercanon", 1998); Ana Peluffo (Lágrimas andinas, 2005); Elena Grau-Lleveria ("Conflictos y pactos en La familia del Comendador", 2005; "Idearios de género para la modernidad limeña finisecular en dos cuentos de Clorinda Matto de Turner", 2019); Nancy LaGreca (Rewriting Womanhood, 2009); y los postulados de Carolina Alzate en su trabajo sobre Soledad Acosta de Samper y el discurso letrado de género (18531881) (2015), por mencionar solo algunos ejemplos.

3 Los lugares de enunciación de estas tres autoras son distintos debido a condiciones sociales, ideológicas y temporales particulares. En el caso de Cabello, la autora pelea por un espacio dentro del campo literario-cultural peruano del momento, con fuertes resistencias bien explicadas por investigadoras como Francesca Denegri (2004 [1996]). En el de Gil de Hermoso, se trata de una escritora triplemente periférica al ser mujer, judía y estar radicada fuera de la capital venezolana (en la ciudad de Coro) (véase Galindo, 2006). En lo tocante a Cáceres, la autora no solo se desenvuelve en tierra europea, sino que, además, goza de un prestigio social e intelectual que le brinda ciertas libertades, aunque no deja de estar constreñida por los sesgos sociosexuales que predominan en el campo literario-cultural del momento (Miseres, 2016). 
4 El uso del término "referente polémico" dialoga con los postulados de Celia Amorós cuando explica que el pensamiento es polémico y su comprensión amerita reconocer con quién o con qué dialoga tensionalmente: "seamos conscientes de ello o no, pensamos con alguien (con mucha gente y, cuanta más, mejor) y sobre todo, contra alguien. Ningún pensamiento se entiende si se desconoce su referente polémico, si no se sabe con quién, de forma explícita o no, se está discutiendo" (Amorós, 2005, p. 39).

5 En esta línea de investigaciones, es posible destacar (por mencionar algunos casos) textos como el de Sylvia Molloy, "Dos lecturas del cisne: Rubén Darío y Delmira Agostini" (1983); el trabajo de Elena Grau-Lleveria en Las olvidadas: mujer y modernismo (2008); las propuestas de Nancy LaGreca, Rewriting Womanhood: Feminism, Subjectivity and the Angel of the House in the Latin American Novel, 1887-1903 (2009); "Intertextual Sexual Politics: Illness and Desire in the Enrique Gómez Carrillo, Del amor, del dolor y del vicio and Aurora Cáceres, La rosa muerta" (2012) y su libro Erotic Mysticism: Subversion and Trascendence in Latin American Modernista Prose (2016); la tesis doctoral de Chantal Berthet, "Body, Gender, and Nation: Women Fiction Writers of Spanish American Modernism" (2014); al igual que el trabajo de Sarah Moody a publicarse próximamente sobre las escritoras del modernismo.

6 Con el carácter antiburgués de dichos prototipos de feminidad me refiero a la manera en que estos personajes femeninos, al igual que las masculinidades del entresiglos vinculadas con el ideario modernista-decadentista, se desligaron del imperativo de productividad que se les imponía desde el proyecto positivista-burgués de modernidad-capitalista que, en el caso de las mujeres, se refería sobre todo a la necesidad de (re)producir los cuerpos y saberes patriarcales en los roles de madresmaestras-cuidadoras.

7 Como lo señala Celia Amorós, en el paradigma hegemónico de la modernidad occidental las masculinidades se asumen como "portadores del logos", mientras la mujer es la gran ausencia sistemática de este discurso, ausencia que "ni siquiera puede ser detectada como ausencia porque ni siquiera su lugar vacío se encuentra en ninguna parte; la ausencia de la ausencia [...] es el logos femenino o la mujer como logos; emerge a veces en el discurso masculino, como una isla en el océano, como lo gratuito y lo inexplicable, lo que inesperadamente se encuentra sin haberlo buscado, y el discurso se configura siempre alrededor de ese islote bajo el signo de la perplejidad, de un oleaje confuso y recurrente que quiere erosionar y tiene a la vez que reconocer contornos, tallar recortes en el discurso para conceptualizar lo imprevisible, el reino dentro de otro reino" (1991, p. 27).

8 La inclusión del término "mujer" entre comillas es una forma de dar cuenta de las connotaciones universalizantes de dicha noción en el período estudiado y, al mismo tiempo, de mostrar los silencios que crea este término en apariencia englobador en relación con factores como la raza, la cultura, la clase social y la edad. Tal como lo explica Lee Skinner en sus reflexiones sobre el problema de la interseccionalidad en la literatura latinoamericana del período (y como puede rastrearse en los textos aquí abordados), "[t]he intersectionality of racial, ethnic, socioeconomic, sexual and gendered identities means that speaking about "women" entails careful differentiations around race, class, and region [...] Many lower-class women in nineteenth-century Latin America may have seen their interests as aligned with lower-class men, not with elite women, and many, although not all, white women did not always understand their experiences as similar to those of women of color, to name but two instances in which gender was far from the dominant category through which people experienced working conditions" (2019, p. 638)

9 Claros ejemplos de esta ambivalente idealización que tiene como subtexto un ejercicio de violencia y contención sobre las feminidades los tenemos en relatos como "Idealismos", de Clemente Palma (1904), o "Un crimen raro," de Ciro Ceballos (1898); pues pese a las diferentes técnicas narrativas, estas obras presentan prototipos de masculinidad que ven en el asesinato de la mujer "amada", bien sea mediante palabras (Palma) o acciones (Ceballos), su instancia de consagración artística. Adicionalmente, ambas obras convergen en la representación de feminidades silentes de cuya supuesta subjetividad solo tenemos conocimiento a partir de lo que las masculinidades perturbadas que las acompañan (y las fatalizan), nos dicen de ellas en sus ejercicios de ventriloquización.

Estas formas de violencia simbólica implícitas en la subyugación del cuerpo mediante la idealización de su pasividad, la concomitante negación del habla y la imposición 
de un discurso monolítico, paradójicamente, no distan demasiado de las estrategias de disciplinamiento ejercidas por las masculinidades legitimadas a través del saberpoder médico a escala social. Al respecto, se sugiere revisar el trabajo de Gabriela Nouzeilles, "La plaga imaginaria", donde se analiza la perspectiva monológica que imponía el saber-poder médico sobre el "cuerpo" de la histérica, transparente al "lenguaje del realismo científico" (2000, p. 181).

10 En La ciudad letrada, Ángel Rama propone la categoría del letrado para definir al tipo de masculinidad que usará la palabra, la literatura y el oficio artístico e intelectual para articular imaginarios nacionales e identitarios (1998 [1984]). El letrado sería, desde la perspectiva de Rama, la figura central de la res publica y no será hasta fines del siglo XIX cuando, según lo explica Julio Ramos (2009), el letrado se desvinculará de la función ideologizante y reclamará para sí un espacio otro de enunciación, autonomía y legitimación para su oficio artístico-intelectual.

11 Entre los trabajos críticos sobre la obra de Cabello destacan las recientes publicaciones de Mónica Cárdenas, "Parodia y política en El Conspirador: Autobiografía de un hombre público (1892), de Mercedes Cabello de Carbonera" (2021); la propuesta de Yolanda Westphalen que ve en las novelas claras resonancias con el contexto político del momento, "Mercedes Cabello de Carbonera: entre la novela de folletín y la ficcio[nacion]alización letrada" (2012), al igual que aportes como el de Christina Mathews, "The Masquerade as Experiment: Gender and Representation in Mercedes Cabello de Carbonera's El Conspirador. Autobiografía de un hombre público" (2005), donde la autora analiza la problematización de los roles sociosexuales en la novela. Se han publicado otras investigaciones a las que no hago referencia aquí por motivos de espacio, y es significativa también la creciente cantidad de tesis de maestría y doctorado enfocadas en el estudio de la obra de Cabello.

12 Las citas directas de la obra de Cabello y las demás novelas referidas en las páginas subsiguientes mantienen la grafía original.

13 Sin mayor arrepentimiento, Bello expresa también su falta al pacto que ha establecido con Ofelia. En esta unión movilizada por intereses políticos, él debía ser responsable de trabajar con ahínco por el partido, empero, cae en la abulia que caracterizaría a muchas masculinidades en crisis del período. En tal sentido, comenta cómo va sintiéndose "sin ánimo, sin entusiasmo para lanzar[se] en ninguna empresa" (Cabello, 1892, p. 202), lo que da indicios de la confiabilidad de su palabra al haber afirmado en reiteradas oportunidades que era Ofelia la causante de su desgracia.

14 Esta referencia a la prostitución no como una forma de degeneración de la mujer, sino como el efecto de la ausencia de posibilidades del sujeto femenino, es una constante no solo en los textos de Cabello (Blanca Sol, 1889, al igual que ensayos como "La necesidad de una industria para la mujer", 1875), sino también en las obras de escritoras relativamente coetáneas como Clorinda Matto de Turner y Adela Zamudio.

15 Bello le pide a Ofelia que guarde silencio para "recuperar su salud" (Cabello, 1892, p. 278). Es interesante cómo el planteamiento higienista es usado por el sistema patriarcal como una estrategia para silenciar a la mujer, sobre todo cuando aborda temáticas problemáticas para su sexo. Sin ánimos de proponer una lectura biográfica, no dejan de ser relevantes las coincidencias entre esta escena en la que Bello le pide silencio a Ofelia por el bien de su salud y una recuperación que se sabe imposible (Ofelia constata la cercanía de la muerte) y los planteamientos de ciertos intelectuales contemporáneos a Cabello que explicaban la locura de la autora no por causa de la sífilis que habría contraído de su licencioso marido, sino por el exceso de actividad intelectual.

16 De hecho, considero que el discurso de Ofelia ayuda a visibilizar la posibilidad de una participación futura de la mujer en la política, como lo planteará la misma Mercedes Cabello en algunos de sus ensayos, por ejemplo, en "El patriotismo de la mujer", donde la autora desarticula el binarismo sociosexual que separa a la mujer de la política, al plantear una genealogía de heroicidades políticas femeninas (véase Pinto, 2017, p. 94). Asimismo, en "La influencia de la mujer en la civilización", la autora ahonda en las facultades políticas de la mujer, por lo que la no participación del sujeto femenino de la política de su tiempo no respondía a una ausencia de capacidad para esa empresa, sino a la falta de condiciones ético-morales necesarias en el momento. Según la autora, la "astucia" y "falsía" que caracterizaban a la política actual eran factores que hacían de ese campo un ámbito inapropiado para el noble corazón femenino (cfr. Pinto, 2017, p. 53). 
17 Elaine Showalter (1985) analiza la poca atención que la crítica ha brindado a la figura de Ofelia de Shakespeare, pese a su presencia persistente en la literatura, la cultura popular y la pintura "from Redon who paints her drowning, to Bob Dylan, who places her on Desolation Row, to Cannon Mills, which has named a flowery sheet pattern after her, is in inverse relation to her invisibility in Shakespearean critical texts" ( $p$. 78). Según Showalter, Ofelia representa "the oppression of women in society", lo que la lleva a plantear la pregunta sobre la crítica feminista y la forma en que ha de representar a la figura de Ofelia en su propio discurso, es decir, la pregunta por "our responsibility towards her as a character and as woman" (p. 78).

18 Según Amorós, las mujeres son vistas desde el ideario patriarcal como sentimentalidad desbordada, naturaleza e instinto, incompatibles con la racionalidad. Por ende, es significativa su determinación a guardar silencio, su capacidad de ocultar sus sentimientos y su compromiso sumo con las mujeres con las que ha crecido.

19 Al respecto, se sugiere revisar el artículo de Luz Ainai Morales Pino (2018), citado en la bibliografía.

20 A este respecto, el título del texto, Incurables, se enmarca en las narrativas de la enfermedad del entresiglos (Nouzeilles, 2000, p.174), no obstante, puesto en diálogo con un extrañado ideario sentimental. Asimismo, si bien el texto no menciona expresamente la anorexia, habla del enflaquecimiento progresivo y, en apariencia, deliberado, de Margarita, lo que puede leerse como un intento extremo de ejercicio de poder y control sobre el cuerpo y el instinto que confronta radicalmente la visión de la mujer como mera fuerza natural incapaz de raciocinio e individuación.

21 Es importante aclarar que el uso de la enfermedad femenina por parte de las escritoras románticas es radicalmente distinto al de los escritores, pues las escritoras usan la enfermedad para expresar un malestar, aunque se trata de un gesto menos radical que el suicidio. Por su parte, los escritores románticos construyen la enfermedad femenina, ya que la mujer enferma deviene un ideal para la masculinidad que desea reiterar su poderío económico y físico. En el entresiglos, las mujeres enfermas presentadas por la pluma masculina retoman esa tradición, pero con un elemento diferencial, que consiste en la forma en que son objeto de inscripción de estas masculinidades que las ven y las crean.

22 El uso de la elocuencia es una estrategia frecuente tanto en los textos aquí revisados, como en otros del período, como " ¡Pálida!... ¡Pero es ella!", de Clorinda Matto de Turner (1893). Un antecedente importante también es el de Dolores, de Soledad Acosta de Samper (1867), donde la enfermedad cumple una función ambigua de condena y liberación, en la medida que imposibilita a la protagonista de casarse, al tiempo que esto le permite dedicarse de lleno a la escritura y al trabajo intelectual. Asimismo, en los momentos de mayor agonía, no deja de expresarse profusamente mediante la escritura. Una constante en los personajes femeninos disidentes respecto a los paradigmas patriarcales es la articulación de un discurso propio del cual ellas devienen los principales sujetos, como sucede por ejemplo en Blanca Sol, de Mercedes Cabello de Carbonera (1891) o La muñeca (1895), de Carmela Eulate Sanjurjo.

23 Si bien la dedicatoria del texto parece retomar el lugar tradicional de la escritura femenina, es decir, la escritura con fines pedagógicos enmarcados en la vocación maternal de la mujer, el texto se desvincula de lo que promete en la dedicatoria para vehiculizar un planteamiento feminista que, no obstante, se mantiene dentro de las convenciones de lo femenino desde el ideario patriarcal (Rivero, 1994). En tal sentido, esta relación tensional entre dedicatoria y novela puede insertarse dentro de la tradición de textos literarios femeninos que vehiculizan sus postulados a través del uso del palimpsesto (Gilbert y Gubar, 2000, p. 73)

24 Este aspecto es relevante para la reflexión sobre el mencionado problema de la interseccionalidad. Si bien el motivo de la mujer viuda es una constante en la literatura del período, no todas las viudeces en todos los contextos son iguales. En cierta literatura escrita por autoras peruanas y ambientada en ese contexto, las mujeres viudas son condenadas a una vida de desgracia debido a la ausencia de posibilidades de superación económica. Empero, en el texto de Cáceres, la viudez de Laura, radicada en suelo europeo y con todo un prestigio socioeconómico, le garantiza una libertad y una holgura impensable para una mujer de otra clase o condición.

25 Igualmente, como lo explica Grau-Lleveria, la vinculación de Laura con el referente de Venus es también tensional, puesto que "frente a la inmovilidad estatuaria de las venus, siempre expuestas a la mirada de los otros, Laura es una venus en constante movimiento y actividad, agente creador del discurso sobre su cuerpo que busca miradas que le confirmen su voluntad de ser" (2018, p. 39). 
26 Para Rebecca Mason (2012), la actitud de Laura muestra su sujeción a los modelos patriarcales que exigen al sujeto femenino hacer de su cuerpo un ideal estético. Empero, en este trabajo sigo la línea de reflexión propuesta por Grau-Lleveria (2018), quien ve en la novela y en el personaje de Laura una contestación al orden patriarcal mediante la desestetización de la enfermedad femenina y, de esa manera, la desarticulación de un ideal de belleza producto de una angustia de las masculinidades ante la posibilidad de poder intelectual y agencia por parte de las mujeres.

27 De esta manera, el personaje dialoga con el de La muñeca, de Carmela Eulate Sanjurjo quien, como lo explica Grau-Lleveria, apela a la moda como una forma de singularización y resistencia frente a los modelos de esposas y madres para los cuales eran educadas. En estos casos, el consumo y el gusto por la moda no responden a mecanismos de desidentificación y dilución identitaria, sino más bien a su conciencia de que, como lo explica la investigadora, "para lograr un proyecto propio, deben de recurrir a mundos en los que se les permite la entrada y que están circunscritos a los espacios imaginarios que las sociedades del momento designaban como femeninos: la moda, el lujo, la pasión por un ideal externo a ellas, la espiritualidad. Es decir, negocian nuevas libertades individuales, pero en nada alteran el sistema patriarcal porque sus proyectos de vida se construyen dentro del territorio de lo que era posible, aceptable y, en algunos casos, deseable para la mujer" (Grau-Lleveria, 2008, p. 53).

28 En la representación de los límites y las falencias de la ciencia y la medicina, el texto dialoga con otras propuestas del entresiglos articuladas por escritores vinculados tanto con el modernismo, como con el decadentismo e, incluso, el naturalismo (pienso específicamente en el caso de Eugenio Cambaceres), en cuyos textos suele aparecer la figura de un médico inútil, ignorante o movilizado por intereses meramente crematísticos.

29 Las referencias intertextuales del texto de Cáceres con la obra de su exesposo, el guatemalteco Enrique Gómez Carrillo, Del amor, del dolor y del vicio (1898) han sido trabajadas por Nancy LaGreca (2012) y Vanesa Miseres (2016), quienes ven en el texto de la escritora una contestación ideológica, estética y política a los planteamientos de Gómez Carrillo.

30 En este punto, vemos un quiebre importante entre la propuesta de Incurables con la enfermedad concebida en términos tensionalmente románticos, y una propuesta como la de Cáceres, donde la enfermedad es biológica, concreta, y confronta radicalmente, en diálogo con las éticas-estéticas modernistas del entresiglos, los límites del saberpoder de la ciencia y la autoridad del facultativo.

31 Al respecto, es fundamental el trabajo de Nancy LaGreca (2012), donde la autora analiza la contestación feminista al discurso patriarcal en el texto de Cáceres, sobre todo en términos de la construcción de la sexualidad femenina como "impulso monstruoso". En tal sentido, LaGreca lee en la novela formas de insumisión y resistencia, sobre todo en la manera en que la autora problematiza la representación del saber y poder de los médicos en el relato (2012, p. 623).

32 Además, Castel, quien inicialmente le indica que no debe tener relaciones sexuales por motivos de salud, termina seduciendo a la paciente y teniendo relaciones sexuales con ella. Esto la hace una suerte de médico-amante-verdugo por ignorancia, negligencia e incapacidad (como se ve en otros textos modernistas-decadentistas del período, como Un adulterio, de Ceballos, 1903). Ahora bien, este aspecto es significativo porque reitera la confrontación de Laura al paradigma de la femme fatale, ya que es una mujer erótica fatalizada por el sujeto masculino.

33 Cabe destacar que las menciones a la sexualidad femenina ya estaban presentes en ciertos textos vinculados con idearios regeneracionistas y pedagógicos, como Luz y sombra (1910), de Ana Roqué.

$34 \mathrm{El}$ ejemplo clave de estas representaciones de la feminidad erótica y sexualizada en clave negativa y destructiva lo vemos en una novela como Un adulterio (1903), de Ciro Ceballos, donde los personajes femeninos que tienen deseo sexual (siempre desvinculado de la maternidad y el matrimonio), son mostrados en clave patológica (ninfómanas, zoófilas) y destructiva para la masculinidad que quiere tener en ellas el consuelo complaciente para las crisis que enfrenta.

35 En esta construcción vital de sí misma, Thomas Ward (2007) ha visto en Laura las trazas de un discurso nietzscheano (p. xviii).

36 Las relaciones sexuales son parte de este proyecto de autoconstrucción artística y singularización, frente al referente polémico que constituyen los cuerpos genéricos y deformados de las mujeres enfermas. Desde esta perspectiva, Laura entraría dentro 
de la definición de lo que Grau-Lleveria ha conceptualizado como las "egoístas" en la literatura escrita por mujeres en el entresiglos y que presentan personajes femeninos que se caracterizan por no solo desmarcarse de las comunidades genéricas de mujeres, sino que demuestran su "habilidad y capacidad de autodefinición [de manera tal que pueden] subvertir, transformar e invertir los modelos tradicionales de comportamiento femenino propios de la época, el valor de los modelos femeninos históricos y transformar el significado que la cultura en general daba a nuevos modelos de mujer surgidos con la modernidad y con la cultura del entre siglos" (2008, p. 52).

37 No me refiero únicamente a las Ofelias inspiradas en la obra prerrafaelista, sino también a toda una serie de pinturas - como la de Cristóbal Rojas, "Primera y última comunión" (1888) - que fijan y convierten en objeto estético la muerte femenina.

38 Paradójicamente, uno de los saberes sometidos más corrosivos es el que evidencia un texto como Incurables, al mostrar cómo una escritora como Virginia Gil de Hermoso, desde los márgenes de la ciudad letrada y desde una condición triplemente periférica como mujer, judía y no residenciada en el centro capitalino, estaba produciendo discursos insertos en un imaginario aparentemente conservador que, no obstante, vehiculizó una cosmovisión feminista que vislumbró la posibilidad de agencias y pactos de igualdad impensables en texto de su estilo.

Con respecto al cuestionamiento al sistema económico en El Conspirador, se recomienda revisar el trabajo de Emily Joy Clark, "Rocambor, Malilla and Matrimony: Gambling in Mercedes Cabello de Carbonera's Naturalist Novels" (2019).

\section{Referencias bibliográficas}

Alzate, C. (2015). Soledad Acosta de Samper y el discurso letrado de género (1853-1881). Madrid, Fráncfort del Meno: Iberoamericana, Vervuert.

Amorós, C. (1991). Hacia una crítica de la razón patriarcal. Barcelona: Anthropos.

Amorós, C. (2005a). La gran diferencia y sus pequeñas consecuencias... para las luchas de las mujeres. Madrid: Ediciones Cátedra.

Amorós, C. (2005b). Dimensiones del poder en la teoría feminista. Revista Internacional de Filosofía Política, 25, 11-33.

Berthet, Ch. (2014). Body, Gender, and Nation: Women Fiction Writers of Spanish American Modernismo. (Tesis doctoral). Universidad de Connecticut, Estados Unidos de América. http://opencommons.uconn.edu/cgi/viewcontent. cgi?article $=6825 \&$ context $=$ dissertations

Cabello de Carbonera, M. (1892). El Conspirador, autobiografía de un hombre público. Lima: Tipografía "La Voce de Italia". https://www.google.com.pe/books/edition/El_conspirador/ BesSAAAAYAAJ?hl=es\&gbpv=1\&printsec=frontcover

Cáceres, A. (2007 [1914]). La rosa muerta (Ed. Thomas Ward). Buenos Aires: Stockcero.

Cárdenas, M. (2021). Parodia y política en "El Conspirador. Autobiografía de un hombre público" (1892) de Mercedes Cabello de Carbonera. América sin nombre, 25, 3342. https://doi.org/10.14198/AMESN.2021.25.02

Ceballos, C. (1898). Un crimen raro. En C. Ceballos, Croquis y sepias (pp. 17-27). Ciudad de México: Eduardo Dublán, Impresor. http: //cdigital.dgb.uanl.mx/la/1020028189/1020028189.PDF

Ceballos, C. (1903). Un adulterio. Ciudad de México: Imprenta de Eduardo Dublan, Impresor. https://www.lanovelacorta.com/facsimiles/un-adulterio.pdf

Clark, E. J. (2019). Rocambor, Malilla and Matrimony: Gambling in Mercedes Cabello de Carbonera's Naturalist Novels. Revista Canadiense de Estudios Hispánicos, 43(3), 507-530. https://doi.org/10.18192/rceh.v43i3.4878

Denegri, F. (2004 [1996]). El abanico y la cigarrera (2. ${ }^{a}$ ed.). Lima: Instituto de Estudios Peruanos y Centro de la Mujer Peruana Flora Tristán.

Felski, R. (1995). The Gender of Modernity. Cambridge: Harvard University Press.

Foucault, M. (2001). Defender la sociedad (2. ${ }^{a}$ reimp.). Ciudad de México: Fondo de Cultura Económica. 
Franco, J. (1989). Plotting women: gender and representation in Mexico. Londres: Verso. Frederick, B. (2006). Harriet Beecher Stowe and the Virtuous Mother. Argentina 18521910. Journal of Women's History, 18(1), 101-120. https://doi.org/10.1353/ jowh.2006.0010

Galindo, D. (2006). En el borde de encaje. Dos sociedades culturales de mujeres en el siglo XIX. Coro, 1890-1895. (Tesis doctoral). Universidad Simón Bolívar, Caracas, Venezuela.

Gil de Hermoso, V. (1905). Incurables. Barcelona: Toribio Taberner. https://www.biblioteca.org.ar/libros/70543.pdf

Gilbert, S. M. y Gubar, S. (2000). The Madwoman in the Attic. The Woman Writer and the Nineteenth Century Literary Imagination (2. ${ }^{a}$ ed.). New Haven, Londres: Yale University Press.

Grau-Lleveria, E. (2008). Las olvidadas: mujer y modernismo. Narradoras de entre siglos. Barcelona: Promociones Publicaciones Universitarias.

Grau-Lleveria, E. (2015). Conflictos y pactos en La familia del Comendador de Juana Paula Manso: Formación de nación a través de políticas matrimoniales. Symposium: A Quarterly Journal in Modern Literatures, 69(1), 38-49. http://10.1080/00397709.2 015.1004277

Grau-Lleveria, E. (2018). La insurrección de la bella muerta en La rosa muerta de Aurora Cáceres. Latin American Literary Review, 45(89), 36-44. http://doi.org/10.26824/ lalr.32

Grau-Lleveria, E. (2019). Idearios de género para la modernidad limeña finisecular en dos cuentos de Clorinda Matto de Turner. Letras (Lima), 90(131), 4-28. http://dx.doi. org/10.30920/letras.90.131.1

Gutiérrez Girardot, R. (1988). Modernismo. Supuestos históricos y culturales (2. ${ }^{a}$ ed.). Ciudad de México: Fondo de Cultura Económica.

LaGreca, N. (2009). Rewriting Womanhood: Feminism, Subjectivity, and the Angel of the House in the Latin American Novel, 1887-1903. Pennsylvania: Penn State University Press.

LaGreca, N. (2012). Intertextual Sexual Politics: Illness and Desire in Enrique Gómez Carrillo's Del dolor, del amor y del vicio y Aurora Cáceres' La rosa muerta. Hispania, 95(4), 617-628. https://doi.org/10.1353/hpn.2012.0141

LaGreca, N. (2016). Erotic Mysticism: Subversion and Transcendence in Latin American Modernista Prose. Carolina del Norte: Department of Romance Studies, The University of North Carolina at Chapel Hill.

Laqueur, Th. (1994 [1990]). La construcción del sexo. Cuerpo y género desde los griegos hasta Freud (Traducción de E. Portela). Madrid: Cátedra.

Ludmer, J. (1985). Las tretas del débil. En J. Ludmer, La sartén por el mango. Puerto Rico: Ediciones El Huracán.

https: / /literaturaanimada.files.wordpress.com/2014/03/ludmer-tretas-deldc3a9bil.pdf

Masiello, F. (1992). Between Civilization and Barbarism: Women, Nation and Literary Culture in Modern Argentina. Lincoln: University of Nebraska Press.

Mason, R. (2012). Destierro, descontrol y distorsión del cuerpo femenino en La rosa muerta de Aurora Cáceres. Hispanic Poetry Review, 9 (2), 63-77.

Mathews, C. (2005). The Masquerade as Experiment: Gender and Representation in Mercedes Cabello de Carbonera's El Conspirador. Autobiografía de un hombre público. Hispanic Review, 73(4), 467-489. https://doi.org/10.1353/hir.2005.0041

Miseres, V. (2016). Modernismo puertas adentro: género, escritura y experiencia urbana en Mi vida con Enrique Gómez Carrillo de Aurora Cáceres. MLN, 131 (2), 399-418. https://doi.org/10.1353/mln.2016.0019

Molloy, S. (1983). Dos lecturas del cisne: Rubén Darío y Delmira Agustini. Revista de la universidad de México, 29, 14-18.

Montaldo, G. (1995). La sensibilidad amenazada. Caracas: Planeta- Fundación CELARG.

Morales Pino, L. A. (2018). En clave heterogénea: éticas y políticas de la caridad en Herencia, de Clorinda Matto, "El velo de la Purísima", de Adela Zamudio e Incurables, de Virginia Gil de Hermoso. Mundo Nuevo. Revista de estudios latinoamericanos, 8 (18), 43-69.

Nouzeilles, G. (2000). La plaga imaginaria: histeria, semiosis corporal y disciplina. Revista de Crítica Literaria Latinoamericana, 26 (52), 173-191. https://doi. org/10.2307/4531127 
Palma, C. (1904). Cuentos malévolos. https://kupdf.net/download/clemente-palmacuentos-malevolospdf_5af462fbe2b6f51f4fc5095a_pdf

Peluffo, A. (2004). Latin American Ophelias: The Aesthetization of Female Death in Nineteenth- Century Poetry. Latin American Literary Review, 32 (64), 63-78. https: / /www.jstor.org/stable/20119929

Peluffo, A. (2005). Lágrimas andinas: sentimentalismo, género y virtud republicana en Clorinda Matto de Turner. Pittsburgh: Instituto Internacional de Literatura Iberoamericana.

Pinto Vargas, I. (2017). Mercedes cabello de Carbonera. Artículos periodísticos y ensayos. Lima: Fondo Editorial del Congreso del Perú.

Pratt, M. L. (1998). Don't Interrrupt Me: The Gender Essay as a Conversation and a Countercanon. Revista Brasileira de Literatura Comparada, 4, 85-101.

Rama, Á. (1998 [1984]). La ciudad letrada. Montevideo: Arca.

Ramos, J. (2009 [1989]). Desencuentros de la modernidad en América Latina. Literatura y política en el siglo XIX. Caracas: El Perro y la Rana.

Rivero, E. (1994). Precisiones de lo femenino y lo feminista en la práctica literaria hispanoamericana. Inti: Revista de literatura hispánica, 40-41, 21-46. https://digitalcommons.providence.edu/inti/vol1/iss40/4

Rousseau, J. J. (2019). Emilio o la educación. Madrid: Editorial Verbum.

Skinner, L. (2019). Ambivalence and Representations of Women's Work in NineteenthCentury Spanish American Writing, 1861-1896. Latin American Research Review, 54 (3), 637-650. https://doi.org/10.25222/larr.149

Showalter, E. (1985). Representing Ophelia: Women, Madness, and the Responsibilities of Female Criticism. En P. Parker y G. H. Hartman (Eds.), Shakespeare and the Question of Theory. Nueva York: Routledge.

Torres-Pou, J. (1998). El e[x]terno femenino. Aspectos de la representación de la mujer en la literatura hispanoamericana. Barcelona: Promociones Publicaciones Universitarias.

Valcárcel, A. (2001). La memoria colectiva y los retos del feminismo. Santiago de Chile: CEPAL-ECLAC.

Ward, Th. (2007). Introducción. En La rosa muerta (pp. vii- xxiv). Buenos Aires: Stockcero.

Westphalen, Y. (2012). Mercedes Cabello de Carbonera: entre la novela de folletín y la ficcio[nacion]alización letrada. En S. B. Guardia (Ed.), Escritoras del Siglo XIX en América Latina (pp. 111-124). Lima: Centro de Estudios la Mujer en la Historia de América Latina. https://www.cemhal.org/Escritoras\%20del\%20siglo\%20XIX.pdf 